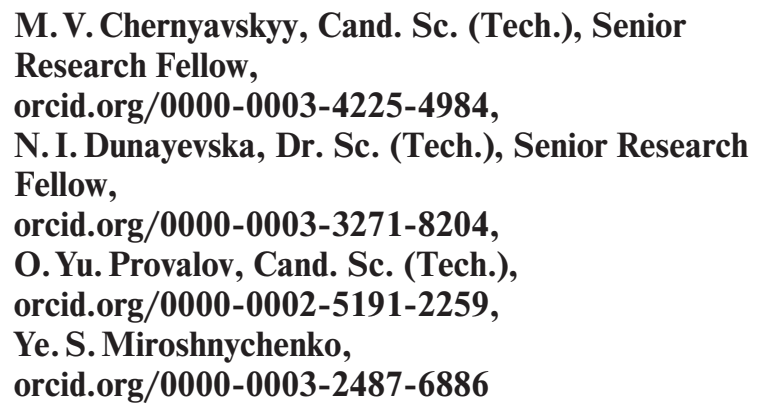

Coal Energy Technology Institute of National Academy of Science of Ukraine, Kyiv, Ukraine, e-mail: ceti@i.kiev.ua

\title{
SCIENTIFIC BASIS AND TECHNOLOGIES OF ANTHRACITE REPLACEMENT AT THERMAL POWER PLANTS
}

Purpose. The development and implementation of technologies for partial and total replacement of anthracite by domestic bituminous coal and fuel mixtures at thermal power plants of Ukraine.

Methodology. Theoretical and experimental studies on the processes of combustion of coal and solid fuel biomass in the pulverized coal flame. Industrial tests at TPPs and CHPPs.

Findings. Technical solutions in conditions of termination of Donetsk anthracite for combusting non-designed fuels and fuel mixtures at 7 thermal power plants are developed. Four anthracite boilers at two thermal power plants have been converted to gas coal and got a new start, while four combined heat and power plants are being converted to such fuels.

Originality. Determination of kinetic characteristics of pyrolysis and combustion of coal of different metamorphism rank, of coal mixtures and solid fuel biomass, improvement of methods for calculation of the dynamics of coal and fuel mixtures combustion in conditions of pulverized coal flame, of methods for estimation and regulation of pulverized coal inclination to spontaneous ignition and explosion.

Practical value. The findings of this study have solved the strategic problem of uninterrupted energy and heat supply from TPPs and CHPPs of Ukraine in crisis conditions of interruption of Donetsk anthracite supplies due to the war actions in the East, the problem of conversion of anthracite power units to bituminous coal of domestic production with the improvement of technical, economic and environmental indicators, expanded the fuel base of TPPs which work on anthracite, and identified the ways to efficient use of Donetsk anthracite after Donbass reintegration. The technical solutions developed have significant prospects for further implementation.

Keywords: anthracite, bituminous coal, thermal power plant, coal combustion

Introduction. Coal thermal power plants are the basis of Ukraine's energy independence. By 2014, they accounted for over $55 \%$ of generating facilities and provided $42-44 \%$ of the total electricity production. In conditions when existing NPP units are capable of bearing only the basic load, and the droughts of recent years have significantly reduced the regulatory capacity of hydroelectric power plants, pulverized coal power units remain the main tool for regulation the energy consumption schedule. 7 of the 14 major Ukrainian thermal power plants (TPPs) are designed for combustion high-volatile steam bituminous coal, and 7 - for low-reactive anthracite and semianthracite combustion; in general, in our country, which is ranked in the top "ten" world coal countries and occupies the third place in the world by anthracite deposits [1], antracite boilers accounted for more than a half of the power generatimg capacity of TPPs, and the mining volumes of steam bituminous and low-reactive coal were approximately the same.

Since 1990s, the constructing of anthracite-fired boilers has gradually stopped worldwide. This was due to the development of low-temperature bituminous coal combustion technologies with solid slag removal, which are characterized by higher efficiency and significantly lower emissions of nitrogen oxides [2]. The world market of anthracite and semianthracite has decreased, only the Russian Federation, South Africa and the USA remain their potential suppliers, the characteristics of their local fuels are different from Ukrainian boilers design requirements.

Ukraine has not had an opportunity to invest in wideranging replacement of anthracite power units for decades, so

(C) Chernyavskyy M.V., Dunayevska N.I., Provalov O. Yu., Miroshnychenko Ye. S., 2020 the replacement of anthracite to other solid fuels did not occur. The situation has changed dramatically with the beginning of war actions in the Donbas in 2014. The deliveries of Donetsk anthracite and semianthracite to TPPs and CHPPs have declined, and completely stopped since 2017. However, in the West Donbas and in the Lviv-Volyn Basin mining of bituminous coal continued and even increased. This made the question of partial or full replacement of anthracite by bituminous coal at TPPs and CHPPs extremely urgent.

However, unlike foreign countries, where such replacement has occurred gradually and with sufficient investments for construction of new modern power units, our country is forced, at least for a transitional period, to seek out such unique technologies that require minimal investments and allow maximum use of available generating and auxiliary equipment of existing anthracite power units.

State of the problem. The main differences between boilers destined for low-reactive and bituminous coal combustion are the design of pulverizing systems, burners and combustion chambers. Most of the pulverizing systems of existing boilers are individual, with ball mills (BM) and pulverized coal bin over which there is the cyclone, which separates pulverized coal itself and a dusty waste drying agent which is discharged into the furnace [3]. Most boilers have molten slag removal, which determines the need to maintain a much higher level of temperature in the lower part of the furnace than the level of ash fluid temperature. To provide a persistent ignition and combustion of low-reactive coal with volatile yield $V^{\text {daf }} \leq 18 \%$ it is necessary to apply swirl burners, discharge of the waste moist-containing drying agent to discharge burners located above the main burners, and heat insulation of the lower part of the furnace ("ignition belt") to increase the flame temperature; at the same time, pulverized low-reactive coal has a low 
inclination to spontaneous ignition and explosion, so it is dried and fed to burners with hot air.

Bituminous coal with volatile yield of $V^{d a f}=35-45 \%$ is less pretentious to ignition and combustion conditions, it permits the use of direct flow burners, the discharge of waste drying agent to the main burners and does not require the "ignition belt"; at the same time, due to the high inclination to spontaneous ignition and explosion of pulverized bituminous coal, it is usually dried and fed to burners by flue gase with oxygen content of not more than $16 \%$. The recirculation of flue gase into the furnace and the lowered flame temperatures determine the need for increasing heat-absorbing furnace walls (screens) to reduce the gas temperature at the furnace exit to the level lower than the temperatures of fly ash slugging.

Replacement of anthracite at thermal power plants is possible in two main ways. The first one is to use mixtures with anthracite and bituminous coal having the same mixture properties as semianthracite has; such replacement is only partial, but it does not require the reconstruction of boilers, burners and pulverizing systems. The second way is to develop technical solutions for reconstruction of anthracite boilers and auxiliary equipment for its complete conversion to bituminous coal in compliance with the requirements of fire and explosion proof operation of pulverizing systems, while the reconstruction cost is as lower as greater the degree of available equipment application is. Both ways require additional knowledge of physical and chemical properties of coal and coal mixtures, characteristics of their ignition and combustion in conditions of pulverized coal flame.

Purpose. Development and introduction of technologies for partial and complete anthracite replacement at thermal power plants of Ukraine by bituminous coal and fuel mixtures on the basis of studies of pyrolysis processes, coal and solid fuel biomass combustion in pulverized coal flame and inclination of pulverized coal to spontaneous ignition and explosion.

Results. Experimental studies were performed on a laboratory-scale plant with the introduction of a coal micro portion into a fluidized bed of preheated inert material, which provided the rate of heating the particles to the bed temperature of $10^{3}-10^{4} \mathrm{~K} / \mathrm{s}$ and the main duration time of gas release in isothermal conditions, using the quick-acting mass-spectrometer to record the dynamics of gas release with the measuring time constant less than $0.5 \mathrm{~s}$ [4]. The studies have found the basic regularities of pyrolysis of coal particles during high-speed heating. Particularly, it was found that at each moment of time gas release occurs in kinetic mode, and the dynamics of the process is determined by the dynamics of the particle heating at the initial stage and by the final temperature of the particles at the main stage, where the gas release rate decreases exponentially over time (Fig. 1).

Effective kinetic characteristics of gas release are determined depending on the particle size and heating conditions. The hypothesis of R. Solomon (1992) was confirmed, that the energy of activation of pyrolysis products release in the thermal decomposition process is not fixed, but is determined by the Gauss distribution around the average value of their link energy, taking into account the influence of the surrounding molecular bonds on it, so the specific yields of gaseous products increase with the increase in temperature due to the involvement in the thermal destruction process of elementary sources with energy activation values as high as the final heating temperature is. The method for calculating the dynamics of pyrolysis at high-speed heating was developed, the time of volatile yield in a pulverized coal flame $(<0.05-0.1 \mathrm{~s})$ was specified [5]. The increase in volatile product formation and reactivity of coke residue in joint anthracite thermolysis with biomass has been experimentally proved [6].

For the quantitative estimation of the specific rate of coke residue burning in pulverized coal flame, the kinetic characteristics were used of the coke residue particles combustion of the coal of different metamorphism degree experimentally
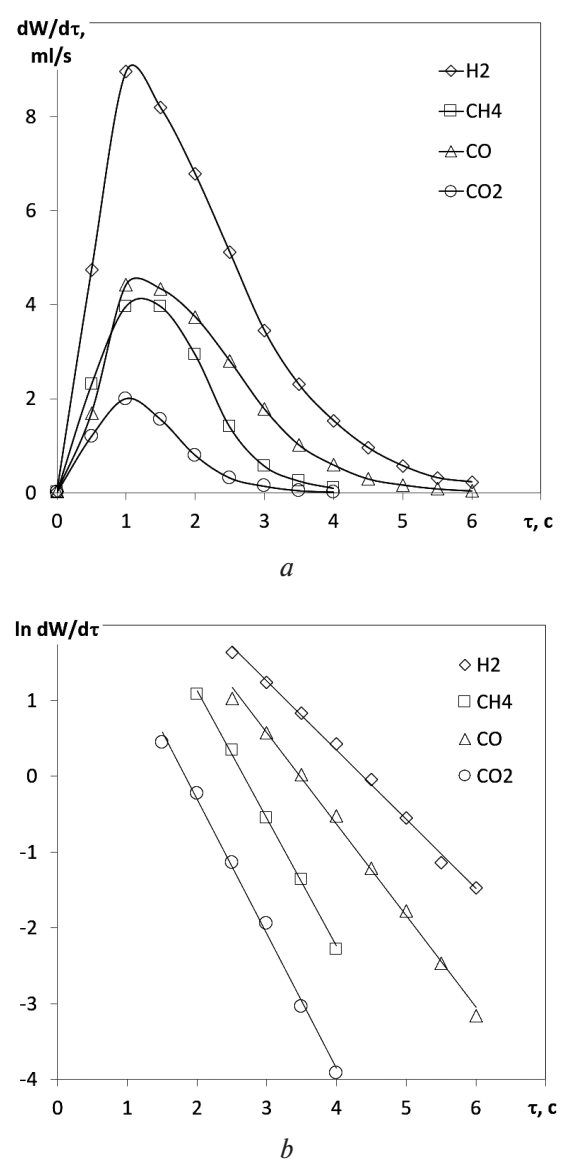

Fig. 1. Dynamic curves of gas release, $\mathrm{ml} / \mathrm{s}(\mathrm{a})$, and logarithmic lines on the declining curve parts $(b)$ during pyrolysis of Donetsk bituminous coal in the pre-heated fluidized bed $(T=$ $=1233 \mathrm{~K}$, particle size $0.6-1.0 \mathrm{~mm}$, portion mass $0.2 \mathrm{~g}$ )

found by Academician O. Maystrenko (1998). A presence of different reactivity types of carbon in coal (free, in coal-mineral splices, in graphitized inclusions) was found, the influence of ash content on the specific burning rate and on the attainable degree of carbon burnout was defined. Methods for calculating the particles combustion rate in the transitional reaction mode have been developed [9]. It was proved that in conditions of pulverized coal flame the bituminous coal burns closer to the external diffusion mode with rather weak power dependence on temperature, and anthracite - to a kinetic mode with a strong exponential dependence on temperature (Fig. 2).

The calculations executed and tests performed on experimental plant with productivity of up to $50 \mathrm{~kg}$ of coal per hour confirmed that, when combusting anthracite in mixture with bituminous coal, the reduction of anthracite combustion rate due to the reduction of oxygen concentration which is spent for volatiles combustion of bituminous coal, provided the air excess, is compensated by the anthracite specific combustion rate increase with the flame temperature rise due to the heat release from volatiles and coke residue of bituminous coal combustion [7]. A similar effect was found for the joint anthracite and solid fuel biomass combustion [6].

We used and substantially specified the pulverized coal explosive criterion $K_{T}$ calculated using coal elementary composition, ash content, volatile yield and lower heat value [8]. In particular, it is shown that $K_{T}$ value is proportional to the volatile yield not of dry ash-free basis $V^{d a f}$, but of dry basis $V^{d}$ (Fig. 3), what means that when the $V^{\text {daf }}$ values are the same, $K_{T}$ value decreases with ash content increase. It is founded that the effective $K_{T}$ value should be proportional to the value of specific reactive surface of the dust particles, i.e. it should increase with the decrease in their size, which is characterized by a value of residue on the sieve of $90 \mu \mathrm{m} R_{90}$, \% (Fig. 4). 

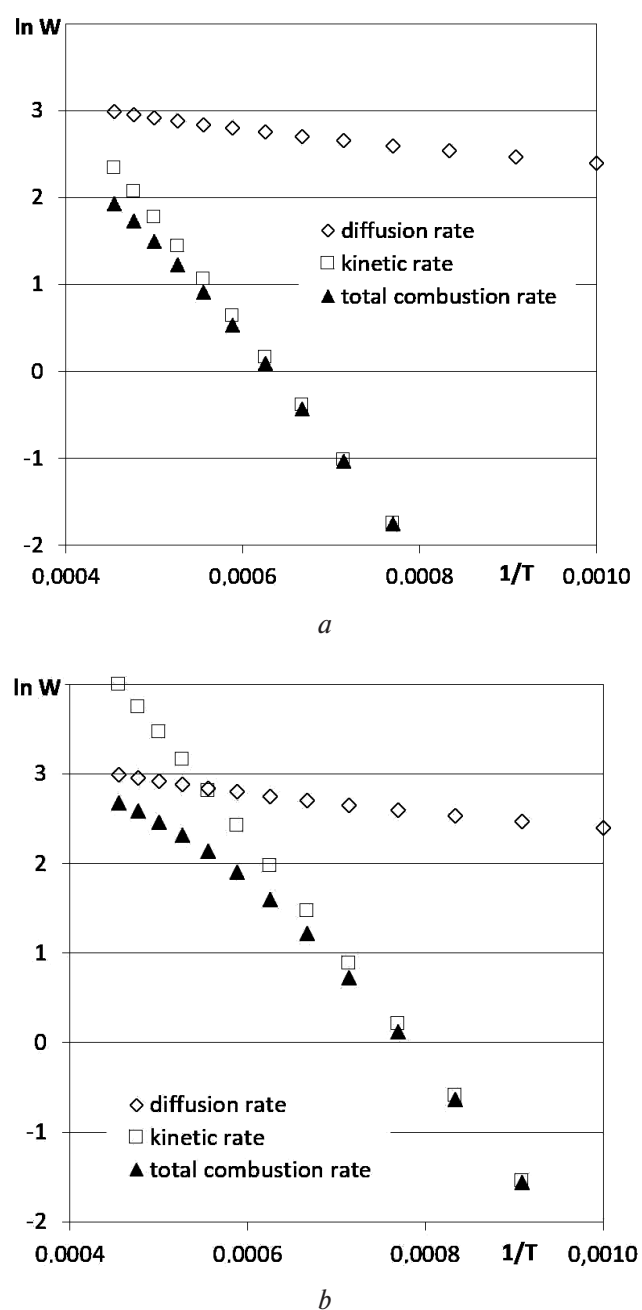

Fig. 2. Dependence of specific combustion rate $W, 1 / s$, on temperature, $1 / K$, for pulverized particles $(d=50 \mu \mathrm{m})$ of anthracite ( $a$ ) and bituminous coal (b)

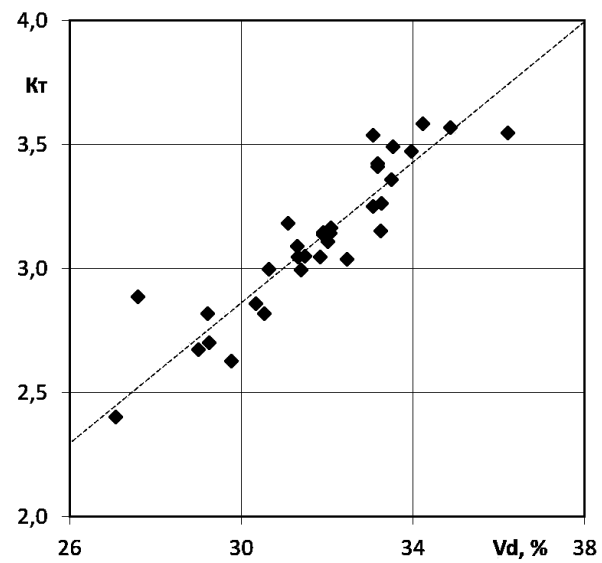

Fig. 3. Dependence of explosive criterion $K_{T}$ value on $V^{d}$ for bituminous coal of Ukrainian production

The results of development and introduction of anthracite replacement technologies at thermal power plants. The complicated conditions of pulverized low-reactive coal ignition and combustion in a flame were mentioned above. The low volatile yield of Donetsk anthracite ( $V^{\text {daf }} \leq 5 \%$ ) forced its combustion for a long time exclusively with a gas/oil stabilizating addition in a part up to $10-15 \%$ by total heat. Since the mid-2000s, the experts from CETI have proposed combustion of anthracite in a mixture with $20-30 \%$ of semianthracite $\left(V^{\text {daf }}=8-18 \%\right)$,

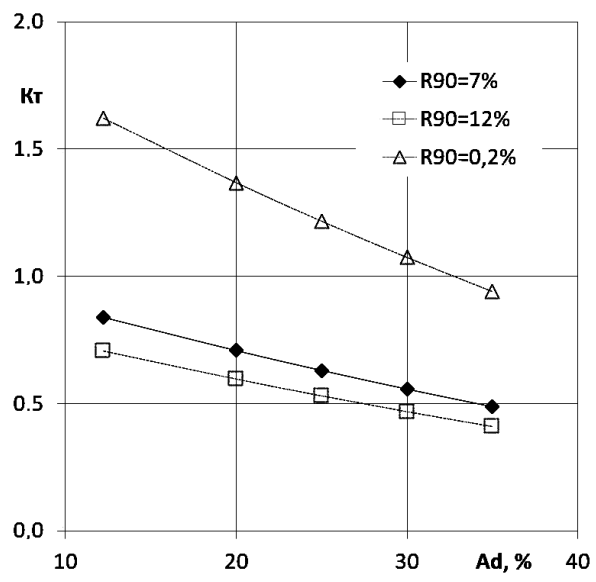

Fig. 4. Dependence of explosive criterion $K_{T}$ value on ash content for different fineness of pulverized semianthracite with $V^{\text {daf }}=16 \%$

which provided the possibility to refuse completely from stabilization addition. However, it should be noted that anthracite and semianthracite belong to the same group of low-reactive fuels; but combustion of low-reactive and bituminous coal mixtures is prohibited by industry regulations both due to the different fire and explosion safety conditions of pulverizing systems and to different combustion features of these fuels.

The possibility of adding $10-12 \%$ of bituminous coal to provide ignition and combustion of anthracite in a flame without stabilizating gas addition in conditions of temporary semianthracite shortage was proved for the first time at the Trypilska and Zmiyivska TPPs of the PJSC "Centrenergo" in 2009, thereat more than 1 million tons of such mixture were combusted. In that case a homogeneous mixture $(G / A$ coal) was produced at the coal preparation plant. In 2015, in conditions of limitation of Donetsk anthracite supplies and complete termination of semianthracite supplies, the task of production of a mixture of anthracite with bituminous coal arose at the coal storage place of Zmiyivska TPP, but with bringing the share of bituminous coal up to $30-32 \%$ for maximum possible replacement of anthracite without reconstruction of boilers. For this purpose, it was necessary to solve scientific and practical problems on homogeneous mixing organization at the TPP's coal storage place and optimization of mixture pulverizing and combustion furnace regime.

The coal storage place of Zmiyivska TPP equipped by two grab cranes and by two belt conveyor galleries along the storage allows mixing by using the "one conveyor - two feeders" technology when feeding anthracite and bituminous coal from different coal piles or from rotary wagon dumpers and return a mixture to srorage place for monitoring. The homogeneity of the mixture is controlled by sampling of a representative number of increments (from the mixture lot up to $1000 t-16$, of $1000-2000 t-24$, of 2000-3000 $t-36$ increments) and by calculation of the mean and standard deviation $(S D)$ values of volatile yield $V^{\text {daf }}$ in increments array. Numerous tests have shown that mixture can be considered homogeneous and that behaves like and should be considered as semianthracite, provided the values of "mean value $V^{\text {daf }} \pm S D$ " do not go beyond the range of semianthracite volatile yield $V^{\text {daf }}=8-18 \%$ ). Herewith, the increments have only $67 \%$ probability to get into this range (Fig. 5, a), but due to an additional mixing when belt-to-belt pouring and in the coal bin, the SD value reduces to less than $1 \%$ while the probability increases to $98 \%$ (Fig. 5, $b$ ).

The tests at TP-100 boilers of $200 \mathrm{MW}$ units and at TPP$210 \mathrm{~A}$ boilers of $300 \mathrm{MW}$ units showed that when combusting a mixture of Donetsk anthracite with volatile yield $4-5 \%$ with $28-32 \%$ of bituminous coal unburned carbon losses in ash reduce to $3.3-4.0 \%$ (when combusting anthracite-semian- 


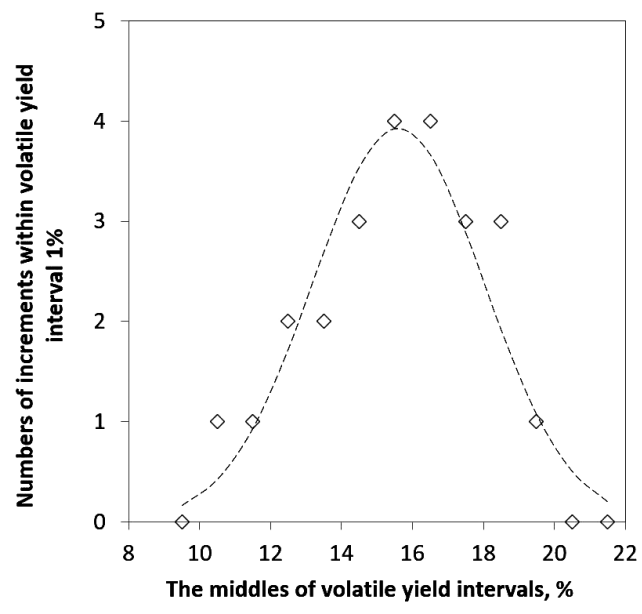

$a$

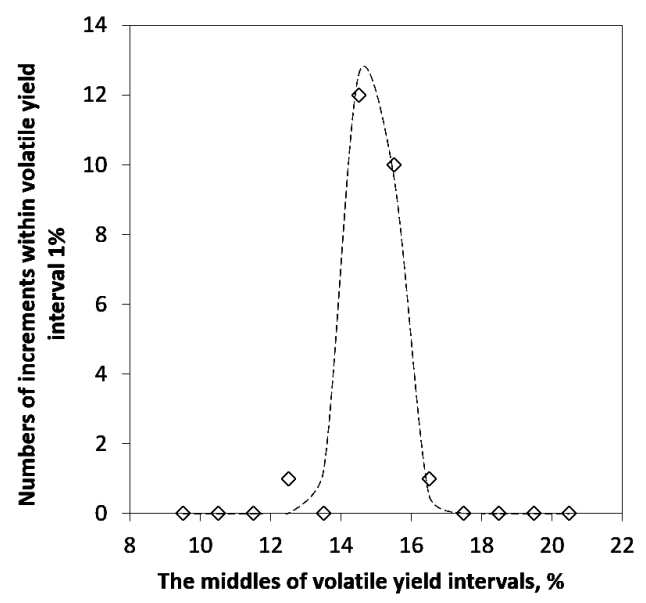

$b$

Fig. 5. Distribution of $V^{\text {daf }}$ values in mixture increments:

$a$-from coal pile, mean value $V^{\text {daf }}=15.5 \%, S D=2.4 \% ; b-$ from raw coal feeder, mean $V^{d a f}=14.9 \%, S D=0.6 \%$

thracite mixture - of 4.0-5.5\%), and the range of load control without stabilizating gas addition increases to $65-100 \%$ (when combusting anthracite-semianthracite mixture - 70$100 \%)$. This, contrary to the traditional view of worsening the anthracite burnout conditions in mixture with more reactive fuel, has fully confirmed the forecast mentioned above for improvement of indicators of combustion of of anthracite in mixture with bituminous coal. During 2016, nearly 1 million tons of such mixture was burned at 200 and 300 MW units of the Zmiyivska TPP, including more than 300.000 tons of domestic bituminous coal, what means that the fuel base of the TPP was increased by one and a half times [7]. In 2017-2018, a mixture of Siberian anthracite with volatile yield of $2.0-2.5 \%$ with $30-35 \%$ of domestic bituminous coal was used as the main fuel at the Krivyy Rih TPP of the PJSC "DTEK Dniproenergo"; in this case, the use of the mixture was the only alternative to stabilizating natural gas addition, without which it was not possible to organize a steady ignition and combustion of antracite with extremely low volatile yield.

The method for composition coal mixtures with set characteristics has also proved to be efficient for combustion of imported fuels with characteristics that differ from designed ones for domestic boilers, such as semianthracite from South Africa, which combined a low heat value (LHV) with high ash fusion temperatures, at Zmiyivska and Trypil'ska TPPs, Darnytska and Chernihivska CHPPs [9].

Among the anthracite thermal power plants Slov'yanska TPP (PJSC "Donbasenergo") stands out, whose $800 \mathrm{MW}$ unit is supplied with pulverized anthracite by high-concentration pipelines from a central pulverizing plant, equipped with nonventilated drying and milling systems composed of steampanel dryers, ball drum mills and mechanical centrifugal separators. The maximum permissible volatile yield for such pulverizing system is $8 \%$, in case of exceeding this level the spontaneous ignition of coal in drying and milling systems, pulverized coal bins and pipelines is inevitable. Filling of non-germetic drying and milling systems of the pulverizing plant with flue gase containing less than $16 \%$ of oxygen is impossible due to the long distance of their transportation from the boiler and inexpedient due to the significant reduction of the boiler efficiency during extraction of large volumes of flue gase. However, the existing standards allow drying bituminous coal in air environment provided that the fuel temperature in any element of pulverizing system does not exceed $70{ }^{\circ} \mathrm{C}$.

Analysis of the drying process at the central pulverizing plant showed that although the temperature of panels where saturated steam condensates is $120-150{ }^{\circ} \mathrm{C}$, during the most part of the drying period the wet coal temperature remains constant and close to the so-called "wet thermometer temperature". This is the temperature that the moist material receives in the unsaturated environment during the process of evaporation of physically and chemically unbound moisture, the lower it is compared to the environment temperature, the lower its saturation degree is [10]. Taking into account the above results of studying of pulverized coal explosive ability, safety modes of drying and milling for coal and mixtures with different volatile yield were developed, which included keeping the moisture content of the dried coal not less than the level of hygroscopic moisture, and increasing the size of pulverized coal particles (pulverized size coarsening) according to the volatile yield increase. With the introduction of these modes at Slov'yanska TPP in 2017-2019, safe and efficient pulverizing and combustion regimes of mixtures of imported anthracite and semianthracite, coal preparation waste, bituminous coal and oil coke with volatile yield of mixtures up to $18-20 \%$ were worked out. Presently, one of three drying and milling systems of the pulverizing plant is fed with the pure bituminous coal, and it is planned to convert the whole TPP to this coal after the completion the testing of combustion modes.

It should be noted that, although the composition of fuel mixtures is quite common worldwide, it is limited to the fuels with close volatile yields and reactivity [11], so that the described examples of application anthracite mixtures with bituminous coal are pioneering. Based on the above positive experience, the national coal quality standard for pulverized combustion and the industrial "Rules for technical operation of power stations and power grids" were amended, 4 standards of enterprises for blending and mixture homogeneity monitoring have been developed. It should be expected that after returning of the Donbas and resumption of Donetsk anthracite supplies, it will be combusted mainly in the composition of mixtures, which will significantly facilitate its ignition and combustion conditions and improve the technical and economic performance of boilers.

The supplies of Donetsk anthracite and semianthracite were completely stopped in 2017. Under these conditions, the task was set to convert 1-2 boilers at each of the anthracite TPPs to bituminous coal combustion. The experience of converting TP-100 boilers of $200 \mathrm{MW}$ units of Zmiyivska TPP to bituminous coal with the use of drying and transport of pulverized coal by flue gase, installation of flue gas recirculation fans (FGRF), replacement of burners and mill fans (LLC "KhDDI TEP-SOYUZ", LLC "Kotloturboprom") [12] showed that traditional methods of re-equipment require significant investments (over 100 million UAH per 1 boiler of $200 \mathrm{MW}$ unit) and a long implementation period, which was not acceptable for all generating companies given the lack of funds and heating season approaching. CETI has chosen the way to convert anthracite boilers to bituminous coal combustion with complete or maximal preservation of existing equipment. 
At the beginning of 2017, Myronivska TPP of the PJSC "DTEK Donetskoblenergo" had 3 operating boilers with steam capacity of $230 \mathrm{t} / \mathrm{h}$ - No 4 TP-230-3 (design fuel - bituminous coal) and NoNo 9, 10 Ep-230-10-510 (design fuelanthracite). Each of the anthracite boilers was equipped with two pulverizing systems including ball mill (BM), separator, cyclone, pulverized coal bin, mill fan (MF). The waste drying air agent after MF with the temperature of $100-110{ }^{\circ} \mathrm{C}$ was divided into 4 streams, three of which transport pulverized coal to the main burners and serve as the primary air, and the fourth one is discharged to the discharging burner located above the main ones. The performed checking consumptionheat calculations of boilers and pulverizing systems proved a possibility to convert the boiler Ep-230-10-510 to bituminous coal with the preservation of the drying air agent without changing the composition and design of the equipment elements, only due to regime measures (pulverized size coarsening, reducing the temperature of pulverize-air mixture at the exit of the mill to $70{ }^{\circ} \mathrm{C}$ ). At the same time, due to the decrease in the discharge drying agent temperature, the blowing is redistributed on registers of the burners in upstream the part of primary air, which correlates with the higher volatile yield of bituminous coal in accordance with the burner designing standards. Air consumption for discharge burners does not exceed $10 \%$ of the stoichiometric value for combustion, which leaves the main burners in excess air conditions and provides optimal conditions for pulverized coal combustion in a furnace. The efficiency of this technological solution was proved by the accident-free operation using bituminous coal of boiler No. 10 of Myronivska TPP since August 2017, of boiler No. 9 - from August 2018.

The task to convert the direct steam flow double body anthracite boiler TPP-210A with supercritical steam parameters of $300 \mathrm{MW}$ unit No 4 of Trypil'ska TPP to bituminous coal was set for the first time in the world. The boiler initially had 3 pulverizing systems with a common pulverized coal bin and supply of pulverized coal to the main burners with high-concentration pipelines under pressure (Fig. 6).

Compared to those used for conversion of Zmiyivska TPP units to bituminous coal, the main technical solutions of CETI differed as follows (Fig. 7): to 2 ;

- the number of pulverizing systems was reduced from 3

- the use of 2 existing hot air fans (HAF) as the FGRF was substantiated to provide gas drying;

- compact centrifugal ash concentrators have been installed in existing gas lines instead of remote cyclones for purification of flue gase selected for drying;

- 2 water injection gas coolers were installed to cool the mill during stop instead of inert gas recirculation fans (IGRF);

- instead of replacement of mill fans by more powerful ones, the existing ones were saved due to organization of high concentration pulverized coal transportation under underpressure;

- instead of replacement of burners, the possibility to save existing burners with their modernization and conversion to the direct-flow/swirl mode sending the waste drying agent to the primary air channel was substantiated.

Decisions on conversion to 2 pulverizing systems, using HAFs as FGRFs, preservation of MFs and installation of injection gas coolers instead of IGRFs were made on the basis of the consumption-heat calculations of the pulverizing systems, taking into account the actual performance of existing equipment and the level of cold air suction. By checking heat calculations by zones of the furnace for the load range of 70-100\% of nominal value the assurance of conditions was justified for molten slag removal and the absence of risk of heating surfaces slagging at the exit of the furnace when combusting bituminous coal. The implementation of the original technical solutions provided the investment savings of more than 90 million UAH. The unit after its technical re-equipment was launched

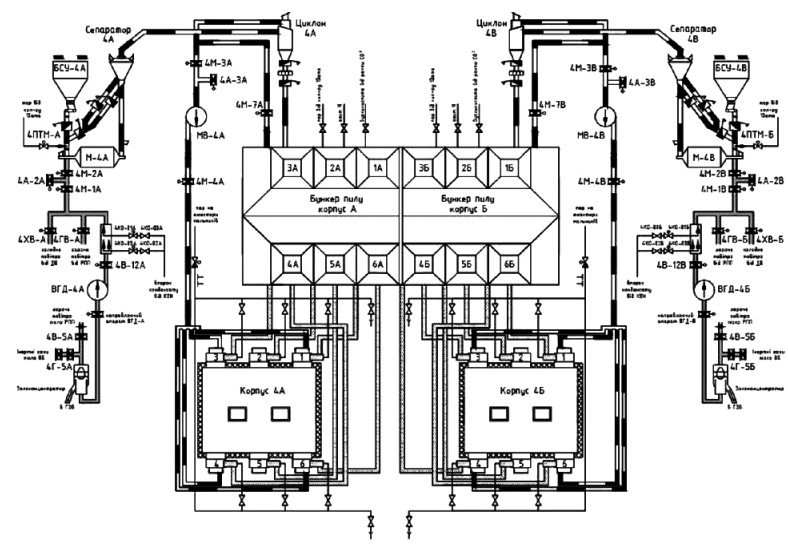

Fig. 6. Layout of the pulverizing system of boilers No. 3 and No. 4 of Trypil'ska TPP before reconstruction

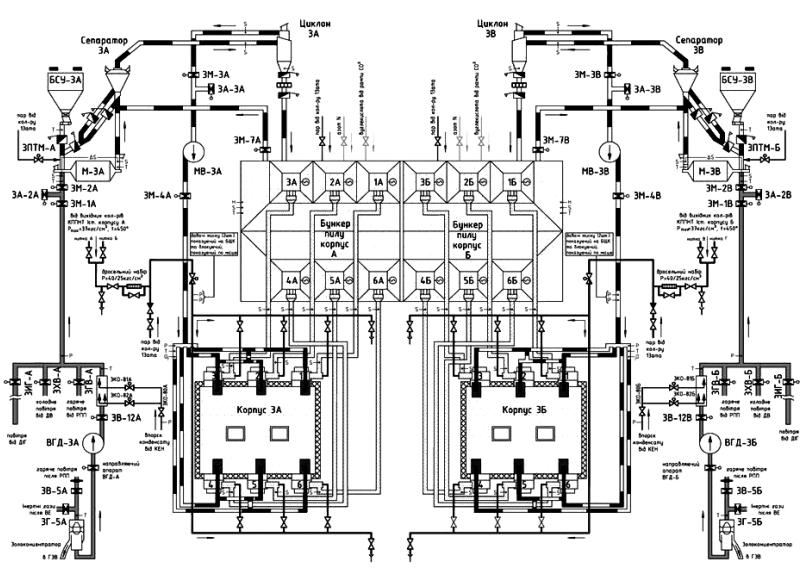

Fig. 7. Layout of the pulverizing system of boiler No. 4 of Trypil'ska TPP after reconstruction

in February 2018, and in 2018-2019 it worked 13.5 thousand hours without any unplanned stop, which proves the efficiency and reliability of proposed technical solutions.

The application of an ordinary for existing bituminous coal-fired boilers discharge of waste drying agent to the primary air channel of the main burners at unit No. 4 boiler ensured the persistent ignition and deep burning of pulverized coal in a flame. However, such scheme is quite difficult in regulation of the air distribution through other channels of burners when load control. In view of this, in the development of technical solutions for conversion the boiler of unit No. 3 to bituminous coal the possibility of discharging the waste drying agent to existing discharge burners was considered.

It is generally believed that the presence of discharge burners when combusting bituminous coal causes the flame elongation because a part of pulverized coal in the waste drying agent is fed above the high temperature flame core, and this results in the increase in the temperature of flue gase and occurrence of slagging conditions at the exit of the furnace. However, the analysis showed that the cause of this elongation is quite different, namely, the lack of an oxidizer in the main burners due to direction of significant part of oxygen required for combustion to discharge burners. The results of the tests of bituminous coal combustion in boilers with discharge burners are known (S. Shagalova, 1976), which proved that the best combustion efficiency is achieved with an excess of oxidant on the main burners $\alpha=1.05-1.10$. Consumption-heat calculations showed that in the case of reconstruction of the TPP$210 \mathrm{~A}$ boiler by reducing the number of pulverizing systems, maintaining the oxygen content level in the drying agent at no more than $16 \%$ and taking into account that $10-15 \%$ of pul- 




Fig. 8. Layout of the pulverized system of boiler No. 3 of Trypil'ska TPP after reconstruction

verized coal is transferred through cyclones to discharge burners, this level of excess oxidant is maintained in the load range of $70-100 \%$. At the same time, the temperature level in the flame core provides a larger reserve for providing conditions of ignition, combustion and molten slag removal. Basing on it, when converting the boiler TPP-210A of unit No. 3 to bituminoius coal the same technical solutions as for unit No. 4 were generally used, but with direction of the waste drying agent to the existing discharge burners (Fig. 8).

Unit No. 3 was launched in January 2019 after reconstruction, and by the end of the year it had worked about 6 thousand hours without unplanned stops, with more simple control mode when load changes and with technical and economic indicators no worse than unit No. 4. Compared to anthracite combustion, the efficiency of both boilers increased by 4-6\%, and the lower load limit without stabilizating gas addition decreased from 70 to $62-65 \%$. The emissions of nitrogen oxides at the reconstructed units have decreased by $10-25 \%$ compared to the anthracite combustion due to decreasing of the mean furnace temperature and optimization of air distribution. In addition, using the above mentioned reserve for providing conditions of ignition, combustion and molten slag removal, for the boiler of unit No. 3 the mode was developed and the tests proved the possibility of the reverse conversion to combustion of semianthracire without changing in the equipment composition, only due to regime measures (pulverized size fining, transition to coal drying with hot air, increase in the temperature of pulverize-air mixture and reduction of the primary air share). Thus, the $300 \mathrm{MW}$ pulverized coal unit No. 3 of Trypil'ska TPP became the first in the world which is able to operate using two fundamentally different types of fuel - bituminous coal or semianthracite.

The implementation of the original technical solutions for the anthracite replacement at TPPs and CHPPs was carried out on the existing equipment, without the right to make a mistake. The effectiveness of technical solutions allowed avoiding radial power outgages and heat supply interruption during heating seasons of 2014-2019, replacing over 10 million tons of anthracite by domestic bituminous coal and imported fuels with non-design characteristics, saving over 60 million $\mathrm{m}^{3}$ of gas, increasing the efficiency and improving the environmental characteristics of pulverized coal-fired boilers. The economic effect of their implementation involves saving gas for stabilizating addition, reducing the unburned losses in ash, having the heat contribution of carbon from wastes, having profit from additional electricity supply, and saving cost of reconstruction units when their conversion to bituminous coal. The economic effect only declarated in appropriate acts for the period of 2014-2018 amounted to 647 million UAH, and taking into account the year 2019, the total economic effect exceeded 1.4 billion UAH.

Prospects for further development. Technical solutions for conversion of $300 \mathrm{MW}$ anthracite units are ready for the further implementation at Zmiyivska and Prydniprovska TPPs. Typical technical solutions for conversion anthracite boilers of CHPPs with steam productivity of $75-250 \mathrm{t} / \mathrm{h}$ to bituminous coal were developed. Technical solutions for preparation and joint combustion of solid fuel biomass with anthracite and bituminous coal in existing boilers of Trypil'ska TPP were prepared, which, in addition to partial replacement of coal, provide reduction of nitrogen oxides, sulfur dioxide and greenhouse gas emissions.

Significant prospects for the application of technical solutions on production and combustion of fuel mixtures will open after the reintegration of the Donbas and resumption of Donetsk anthracite supplies. Given the above mentioned difficulties when low-reactive anthracite combustion, it can be expected that TPPs and CHPPs will need them exclusively in a form of mixtures with bituminous coal having the same mixture characteristics as semianthracite.

The results of theoretical and experimental studies on the features of pyrolysis, coal and solid fuel biomass combustion, the inclination of pulverized coal to spontaneous ignition and explosion, the developed methods for calculation of the pulverized coal preparation and combustion processes form the scientific basis for the development of the latest safe in operation, highly efficient and environmentally friendly technologies of the solid fuel energy in Ukraine.

Conclusions. Based on the results of studies on determination the kinetic characteristics of pyrolysis and combustion of various metamorphism rank coal, coal mixtures and biomass, improvement of methods for calculating the dynamics of burning out the coal and fuel mixtures in conditions of pulverized coal flame, methods of evaluation and regulation of coal inclination to ignition and explosion, a series of unique innovative technical solutions and technologies for partial and complete replacement of anthracite by domestic bituminous coal and fuel mixtures at thermal power plants of Ukraine has been developed and implemented. The most significant among them are production and combustion of a mixture of anthracite with $30-35 \%$ of bituminous coal, the conversion of anthracite-fired boilers of TPPs and CHPPs to bituminous coal 
combustion with full or maximal use of existing equipment. According to the developed technical solutions, in conditions of termination of Donetsk anthracite supplies non-design fuels and fuel mixtures were successfully combusted at 7 thermal power plants, 4 anthracite-fired boilers at two TTPs were converted to bituminous coal and got a new life, while four CHPPs are in the process of such conversion. The $300 \mathrm{MW}$ pulverized coal unit No. 3 of Trypil'ska TPP became the first in the world which is able to operate using two fundamentally different types of fuel - bituminous coal or semianthracite.

All mentioned above allowed avoiding radial power outages and heat supply interruption during heating seasons 2014-2019, replacing more than 10 million tons of anthracite by domestic bituminous coal and imported fuels with nondesign characteristics, saving more than 60 million $\mathrm{m}^{3}$ of gas, increasing the efficiency and improving the environmental characteristics of pulverized coal-fired boilers. For the period of 2014-2018 the confirmed economic effect amounted to 647 million UAH, and taking into account the year 2019, it exceeded 1.4 billion UAH. The developed technical solutions have significant prospects for the further implementation.

Acknowledgements. The study "Scientific bases of innovative technologies for anthracite replacement in energy and their implementation" was awarded by the State Prize of Ukraine in science and technology for 2019. We are grateful to our co-authors P. Kravets (Trypil'ska TPP), I. Babenko (Zmiyivska TPP), O. Moiseyenko (Ukrainian research institute of coal preparation and briquetting) for their active participation in the implementation and regulatory support of the developed technical solutions. We are also grateful to the specialized commissioning organizations "Techenergo" and "LvivORGRES" for their participation in the tests during implementation of the developed technical solutions.

\section{References.}

1. Anthracite Market Survey: An in-depth report on the world anthracite market. Copyright Resource-Net, Cape Town, South Africa. (August 2017). Retrieved from http://www.resource-net. com/index.php/anthracite-market-survey.

2. Dipak, K. Sarkar (2015). Thermal power plant: Design and Operation. Elsevier Inc. https://doi.org/10.1016/B978-0-12801575-9.00001-9.

3. Nazmeyev, Yu. G., \& Mingaleyeva, G. R. (2005). Dust Supply and Dust Preparation Systems for TPPs: A Reference Guide. Moscow: Izd. dom MEI.

4. Chernyavskiy, N. (2003). The main natural laws of highrate coal pyrolysis. Thermal Science, 2 (7), 77-87.

5. Bondzik, D.L., Duliyenko, S.G., \& Chernyavskiy, N.V. (2005). Method and results of calculating the dynamics of gas evolution during high-speed coal pyrolysis. Ekotekhnologii $i$ resursosberezheniye, 6, 3-14.

6. Dunayevska, N. I., Chernyavskiy, M. V., \& Shchudlo, T. S. (2016). Co-combustion of solid biomass in pulverized anthracite-coal firing boilers. Ukrainian Food Journal, 5, 748-764. https://doi.org/10.24263/2304-974X-2016-5-4-14.

7. Cherniavskyi, M. V., Provalov, O. Yu., Beztsennyi, I. V., \& Moiseienko, O. V. (2016). Development of methods and practical experience in the preparation and pulverized combustion of anthracite and bituminous coal mixture at Zmiev TPP. Ekotekhnologii i resursosberezheniye, 4, 3-12.

8. Xiao, C.W. (2016). Study on explosion characteristics of pulverized coal and explosion proof measures of coal bunker. J. Power System Engineering, 44(8), 188-192.

9. Chernyavskiy, N. V., Rokhman, B. B., Provalov, A. Yu., \& Kosyachkov, A.V. (2015). Experience of burning imported coal in boilers of TPPs and CHPs. Energotekhnologii i resursosberezheniye, 4, 15-23.

10. J. M.P. Q. Delgado, A. Gilson Barbosa de Lima (2016). Drying and Energy Technologies. Springer international Publishing, Switzerland, Retrieved from https://link.springer. com/book/10.1007\%2F978-3-319-19767-8.
11. Tillman, D., Duong, D., \& Harding, N.S. (2012). Solid Fuel Blending. Principles, Practices, and Problems. UK: Butterworth Heinemann. Retrieved from https://www.elsevier.com/books/solid-fuel-blending/tillman/978-0-12-380932-2.

12. Hulia, O. M. (2017). Effective technologies are the basis for sustainable development of energy and energy security of Ukraine. Proc. of the $1^{\text {st }}$ International Conference "Power Engineering of Ukraine. The current state and prospects of development”, Kharkiv, 25 April 2017. Retrieved from https://uaea. com.ua/meta-reports.

\section{Наукові основи й технології заміщення антрациту на теплових електростанціях}

\author{
М. В. Чернявський, Н. І. Дунаєвська, О. Ю. Провалов, \\ Є. С. Мірошниченко
}

Інститут вугільних енерготехнологій НАН України, м. Київ, Україна, e-mail: ceti@i.kiev.ua

Мета. Розроблення та впровадження технологій часткового й повного заміщення антрациту на теплових електростанціях України вітчизняним газовим вугіллям і паливними сумішами.

Методика. Теоретичні та експериментальні дослідження процесів горіння вугілля та рослинної біомаси в пиловугільному факелі. Промислові випробування на ТЕС i ТЕЦ.

Результати. Розроблені та впроваджені технічні рішення в умовах припинення поставок донецького антрациту для спалювання непроектного палива й паливних сумішей на 7 електростанціях. На газове вугілля переведені та отримали нове життя 4 антрацитові котлоагрегати на двох ТЕС, на чотирьох ТЕЦ таке переведення триває.

Наукова новизна. Визначення кінетичних характеристик піролізу й горіння вугілля різного ступеню метаморфізму, вугільних сумішей і біомаси, удосконалення методів розрахунку динаміки вигоряння вугілля й паливних сумішей в умовах пиловугільного факелу, методів оцінки та регулювання схильності вугільного пилу до самозаймання й вибуху.

Практична значимість. Результати роботи вирішили стратегічну проблему безперебійного енерго- та теплопостачання з ТЕС і ТЕЦ України у кризових умовах припинення поставок донецького антрациту внаслідок бойових дій на сході, проблему переведення антрацитових енергоблоків на газове вугілля вітчизняного видобутку з покращенням техніко-економічних і екологічних показників, розширили паливну базу антрацитових ТЕС, визначили шляхи ефективного використання донецького антрациту після реінтеграції Донбасу. Розроблені технічні рішення мають значні перспективи подальшого впровадження.

Ключові слова: антрацит, газове вугілля, теплова електростанція, пиловугільне спалювання

\section{Научные основы и технологии замещения антрацита на тепловых электростанциях}

\section{Н. В. Чернявский, Н. И. Дунаевская, А. Ю. Провалов, E. С. Мирошниченко}

Институт угольных энерготехнологий НАН Украины, г. Киев, Украина, e-mail: ceti@i.kiev.ua

Цель. Разработка и внедрение технологий частичного и полного замещения антрацита на тепловых электростанциях Украины отечественным газовым углем и топливными смесями. 
Методика. Теоретические и экспериментальные исследования процессов горения угля и растительной биомассы в пылеугольном факеле. Промышленные испытания на ТЭС и ТЭЦ.

Результаты. Разработаны и внедрены технические решения в условиях прекращения поставок донецкого антрацита для сжигания непроектного топлива и топливных смесей на 7 электростанциях. На газовый уголь переведены и получили новую жизнь 4 антрацитовые котлоагрегата на двух ТЭС, на четырех ТЭЦ такой перевод продолжается.

Научная новизна. Определение кинетических характеристик пиролиза и горения угля разной степени метаморфизма, угольных смесей и биомассы, совершенствование методов расчета динамики выгорания угля и топливных смесей в условиях пылеугольного факела, методов оценки и регулирования склонности угольной пыли к самовозгоранию и взрыву.
Практическая значимость. Результаты работы решили стратегическую проблему бесперебойного энерго- и теплоснабжения с ТЭС и ТЭЦ Украины в кризисных условиях прекращения поставок донецкого антрацита в результате боевых действий на востоке, проблему перевода антрацитовых энергоблоков на газовый уголь отечественной добычи с улучшением технико-экономических и экологических показателей, расширили топливную базу антрацитовых ТЭС, определили пути эффективного использования донецкого антрацита после реинтеграции Донбасса. Разработанные технические решения имеют значительные перспективы дальнейшего внедрения

Ключевые слова: антрацит, газовый уголь, тепловая электростанция, пылеугольное сжигание

Recommended for publication by B. B. Rokhman, Doctor of Technical Sciences. The manuscript was submitted 17.12.19. 